\title{
Sectorial Contributions of Non-Oil Revenue to Economic Growth in Nigeria
}

\author{
Samson Oluwole Olowo', Kehinde Omolade Daramola², Odunayo Femi Ogunsanwo ${ }^{2}$, \\ Damilola Gabriel Edewusi ${ }^{1}$
}

\author{
${ }^{1}$ Department of Finance, Faculty of Management Science, Ekiti State University, Ado-Ekiti, Ekiti State, Nigeria \\ ${ }^{2}$ Department of Finance, Faculty of Management Science, Federal University Oye-Ekiti, Ekiti State, Nigeria \\ Email: odunayoogunsanwo651@gmail.com
}

How to cite this paper: Olowo, S.O., Daramola, K.O., Ogunsanwo, O.F. and Edewusi, D.G. (2020) Sectorial Contributions of Non-Oil Revenue to Economic Growth in Nigeria. Open Access Library Journal, 7: e6644.

https://doi.org/10.4236/oalib.1106644

Received: July 23, 2020

Accepted: August 23, 2020

Published: August 26, 2020

Copyright $\odot 2020$ by author(s) and Open Access Library Inc.

This work is licensed under the Creative Commons Attribution International License (CC BY 4.0).

http://creativecommons.org/licenses/by/4.0/

\begin{abstract}
The study examined the sectorial contributions of non-oil revenue to economic growth in Nigeria from 1981 to 2018 with the aim of examining the effects of environmental, information and communication technology and financial sectors' revenue to economic growth in Nigeria. Autoregressive distributed lag model was the main estimation technique applied. The time series data for the study on environmental sector revenue, information and communication technology sector revenue, financial sector revenue and real gross domestic product were secondarily sourced from the Central Bank of Nigeria's Statistical Bulletin. The study found that environmental sector revenue has positive and insignificant contributions to economic growth whereas there information and communication technology and financial sectors' revenue contributed positively and significantly to economic growth in Nigeria. The study, thus, implies that the sectorial contributions of non-oil revenue undermined. It is concluded that sectorial contributions of non-oil revenue is positive and significant to economic growth in Nigeria. Recommendations were made that, environmental, ICT, financial among others non-oil sectors should receive the same magnitude of fund as in the case of oil sector, i.e., the sector should be more funded and well equipped to ensure good outputs and contributions; government should review environmental factors and policy that may spur the economy significantly.
\end{abstract}

\section{Subject Areas}

Economics

\section{Keywords}

Sectorial Contribution, Environmental Sector, Information and

Communication Sector, Finance Sector, Non-Oil Revenue, Economic 
Growth, ARDL, Nigeria

\section{Introduction}

The contributions of oil sector revenue to economic growth of a country especially developing countries like Nigeria can never be overemphasised, this implies that the contributions of oil sector revenue have always been encouraging and on the increase. Hitherto, oil contributes over $\$ 231$ billion in rents for the Nigerian economy and these rents have constituted between 21 percent and 48 percent of Gross Domestic Product, nonetheless, the effects have not assisted to alleviate poverty and unemployment currently embattling the nation (Okezie \& Azubike, 2016) [1]. This is enough reason for government to diversify into non-oil sector in order to compliment revenues with oil revenue. The study advocates that if Nigeria aims to be the real "giant of Africa" as claimed, efforts must be made by the government to foster attention to the non-oil sector otherwise, the worse is yet to come. As a result, Nigeria's over dependence on crude oil revenue has affected the economy negatively, thereby, reducing the productivity in the economy, no doubt that oil revenue has contributed substantially to revenue generation and growth of Nigeria's economy (Sanusi, 2003) [2]. Nonetheless, revenue generation from oil has begun to drop as a result of general price fluctuation which calls for diversification into the non-oil sector before it gets out of hands.

For this reason, non-oil sector is referred to as those groups of economic activities that are outside the petroleum and gas industry forms a crucial sector in Nigeria (Ude \& Agodi, 2014) [3]. To buttress this, Adulagba (2011) [4] and Onwualu (2012) [5] classified non-oil sector into construction sector (building); telecommunication services; financial sector (banking and insurance) services; tourism service (hotels, restaurants, parks, carnivals, movies; wholesale and retail trade); health services; export trade; agricultural activities; mineral activities; power (conventional and renewable); transportation services (road transportation, rail transportation, water transportation, air transportation, and post and courier services); manufacturing; environmental services (cleaning, waste collection and recycling); Research and Development (R \& D) activities; Information and Communication Technology (ICT), environmental sector; wholesale and retail sector, etc.

Each of these activities consists of various businesses which engage a large chunk of the population. For instance, Tourism consists of hotels and restaurants, resorts/recreation parks, cultural activities, carnivals, movie industry, arts and crafts, comedy, etc. When viewed from this background, the general assumption that the non-oil sector refers to agricultural and mineral activities alone is not true and makes the assessment of the sector narrow (Onwualu, 2012 [5]; Dauda, Asinbo, Akinbode, Saka \& Salihu, 2009 [6]). In addition, one of the 
most effective and efficient means of internal revenue generation for government is through the tax system (Ayuba, 2014) [7]. In support of the benefits attributed to tax revenue, Nzotta (2007) asserted that taxes constitute the key sources of finance to the federation account distributed among the three tiers of government (Garba, 2014) [8].

These non-oil sectors have the potential or capacity to provide food for human population, and act as source of raw materials for industries and thus, promote economic growth and poverty reduction. In the years between 2008 and 2014, non-oil revenue marginally increased from $45.09 \%$ to $48.01 \%$ (National Bureau of Statistics, 2014) [9]. This showed that if government devotes much effort to revenue generation from the non-oil sector, the flow of government revenue will be sustainable and appreciable overtime. According to Izuchukwu (2011) [10], the non-oil sectors have the potentials of providing employment opportunities for the teeming population and thereby contributing to the growth of the economy.

Thus, government needs to further diversify into other sectors like environmental sector, ICT sector and financial sector of economy become imperative due to the dwindling oil revenue. Hence, Government should put in vigorous measures that can revitalize the non oil sector of the economy in order to strengthen the sources of revenue generation available to the nation. To this end, the study investigates the sectorial contributions of non-oil revenue to economic growth in Nigeria with the aim of establishing the contributions of environmental sector, ICT sector and financial sector to economic growth in Nigeria.

The study is motivated by the current crash of oil price all over the world which has the propensity to deteriorate a growing economy, thus, the need for government to tactically diversity into other sector (non-oil) of the economy especially environmental sector, ICT sector and financial sector which have been tested to produce significant result in literature. The importance of these sub-sectors is germane at a time like this when the world is battling with various challenges, thus, investment into environmental, ICT and financial sector cannot but well appreciated, this is because, a naira devoted or contributed into the sector today will certainly serve as a saving ground for the economy sooner than later, thereby enhancing economic growth to a productivity state where it can compete with other developing countries of the world.

\section{Literature Review}

\subsection{Theoretical Framework}

Theory of growth rate maximization forms the basis of this study. Marris, in 1964, developed a dynamic balanced growth maximizing model of the firm. He concentrated on the proposition that modern big firms are managed by managers and the shareholders are the owners who take decision about the management of the firms. Whereas the managers aim at maximizing the growth rate of the firm, the shareholders aim at maximizing their dividends and share prices. 
To strike a balance between the objectives of the two parties, Marris developed the balanced growth model in which the manager chooses a constant growth rate at which the firm's sales, profits, assets and other performance variables grow. In this way, the goals of the managers and firm owners are brought into congruence as both parties try to achieve a balanced growth. This theory is based on the assumption that there is a given price structure, a given production costs, absence of oligopolistic interdependence, constant factor prices, firms grow through diversification, and all major variables such as profits, sales, costs, and assets grow at the same rate. The implication of this theory is that management should strive to achieve a growth rate through diversification of non-oil product.

Ihendinihu, Ebieri and Ibanichuka (2014) [11] opined that government earns revenue from two major sources namely; oil and non-oil revenue. Oil revenue is the most important source of revenue to the federal account. Oil revenues are revenues from crude oil and gas exports, receipts from petroleum profits tax and royalties and, revenue from domestic crude oil sales while non-oil revenue which is the second categoryof revenue to the federal account include revenues that are not derived from or associated with oil. They include; companies income tax, custom and excise duties, valued added tax, education tax, personal income tax (PIT), Levies, public debt, grants, aids amongst others. Non-oil revenue is, therefore, the income or proceeds generated from the commodities that are sold in the foreign market excluding crude oil (petroleum product). These non-oil sectors revenues are proceeds from agricultural products or crops, manufactured goods, tourist services/receipts, solid minerals, telecommunication services, environmental service, ICT services, financial services and other exports (Ogba, Park, \& Nakah, 2018) [12].

Ullah and Rauf (2013) [13] noted that whenever there is an increase in real GDP of a country, it will boost up the overall output. The economic growth is helpful to increase the incomes of the society, help the nation to bring unemployment to low level and also help in the deliveries of public services. Haller (2012) [14] opined that economic growth is a complex, long-run phenomenon, subjected to constraints like: excessive rise of population, limited resources, inadequate infrastructure, inefficient utilisation of resources, excessive governmental intervention, institutional and cultural models that make the increase difficult, etc. Economic growth is obtained by an efficient use of the available resources and by increasing the capacity of production of a country. It facilitates the redistribution of incomes between population and society. The cumulative effects, the small differences of the increase rates, become big for periods of one decade or more. It is easier to redistribute the income in a dynamic, growing society, than in a static one.

\subsection{Empirical Review}

Tabari and Nasrollahi (2010) applied vector error correction model methodology to estimate the short and long-run effects of Iranian non-oil exports on out- 
put during the period 1980-2007. The study used an augmented neoclassical production function type. The results indicate negative effects of non-oil export on non-export output, while capital stock and labour force have positive effects on non-export GDP.

Okezie and Azubike (2016) [1] evaluated the contributions of non-oil revenue to government revenue and economic growth in Nigeria from 1980 to 2014. The study applied ordinary least square (OLS) multiple regression econometric tool as the estimation technique, the study attempted to analyse the relationship between the independent variables of Non-oil Revenue and oil revenue and the dependent variables of economic growth proxied by Gross Domestic Product (GDP) and Total Government Revenue (TOREV) variables. The study developed two models to address the objectives. Findings from the study indicated a positive and significant contribution of non-oil revenue to economic growth but slightly insignificant contribution to government revenue. The study contributed to knowledge based on the significant result, however, the study can be best examined by using sub-sector of non-oil sector, this is to account for a more productive sub-sector against others. Idowu (2016) [15] investigated the role of oil and non-oil exports on the Nigerian economy over the period of 1981 to 2015. The Augmented Dickey Fuller and Phillip Perron unit root test, Johansen cointegration test, Granger causality test, impulse response functions (IRF) and variance decomposition (VD) were used in the analysis of the study. The cointegration test indicates that there is a long run relationship among the studied variables. Furthermore, the Granger causality test indicates short run unidirectional causality running from oil export to GDP. There are also bidirectional long run causality relationship between oil export and GDP, and unidirectional long run causality running from non-oil export to GDP. The study's result indicates that oil exports have inverse relationship with economic growth while non-oil exports have positive relationship with economic growth. Nonetheless, a more detail study on specific non-oil sectors is recommended for future researcher. This will assist the present study to delve into specific non-oil contributions to economic growth in Nigeria.

Nweze and Edame (2016) [16] examined oil revenue and economic growth in Nigeria between 1981 and 2014. Secondary data on gross domestic product (GDP) was used as a proxy for economic growth; oil revenue (OREV), and government expenditure (GEXP) which represented the explanatory variables were sourced mainly from CBN publications. In the course of empirical investigation, various advanced econometric techniques like Johansen Cointegration Test and Error Correction Mechanism (ECM) were employed. The cointegration result indicated that there is a long run relationship among the variables with three cointegrating equation(s). The result of the error correction mechanism (ECM) test indicates that all the variables except lag of government expenditure exerted significant impact on economic growth in Nigeria. However, all the variables exhibited their expected sign in the short run but exhibited negative relationship 
with economic growth in the long run except for government expenditure, which has positive relationship with economic growth both in the long run and short run. The study concluded that Government should use the revenue generated from petroleum to invest in other domestic sectors such as Agriculture and manufacturing sector in order to expand the revenue source of the economy and further increase the revenue base of the economy. This study established that government should diversify into Agriculture and manufacturing sectors, hence, this study will examine the effect of other non oil revenue sectors on economic growth.

Idris and Ahmad's study (2017) [17] aimed at evaluating the influence of tax revenue on the macroeconomic management of the Nigerian economy using a conceptual approach. In view of this, the study explored the revenue trend in Nigeria for over three decades in relation to its effects on GDP growth. Evidence from the finding revealed that existence of causal relationship between tax revenue and economic growth suggests the positive influence of taxation as a fiscal policy tool in enhancing macroeconomic growth. This is certainly the policy implication of Keynesian propositions. On the other hand, non-existence of causal relationship between tax revenue and economic growth implies that taxation as a fiscal variable shall be insignificant especially in the long run, as propounded by the Classical doctrine. In spite of the aforementioned policy importance, the percentage of tax revenue as a share of GDP in Nigeria remains positive but relatively low. This is attributed to the increased dependency of the economy on oil revenue while neglecting other potential sources especially in the areas of non-oil growth such as agriculture, solid minerals, and small-and-medium enterprises. Nwafor (2017) [18] focused on the effect of non-oil export on Nigerian Economy over a period of 2004 to 2013. The study formulated two hypotheses and was tested through ordinary least squares regression technique. The study concluded that non-oil exports have positive significant impact on economic growth of Nigeria and that non-oil exports have positive and significant impact on the value of Nigerian currency.

Apere (2017) [19] empirically examined the role of crude oil on fiscal policy in Nigeria with annual secondary time series data over the period 1980 to 2015 obtained from the Central Bank of Nigeria's (CBN) statistical bulletin. The vector auto regression (VAR) model was used as data analysis technique. Evidence from the study indicated that all the variables were stationary, using the Phillip-Perron unit root test, and having determined the stationarity of the variables, the Lag length selection of fifth lag was selected; and VAR stability tests result which affirmed that VAR model is dynamically stable and useful for policy analysis. VAR LM test for serial correlation indicated that the model has no serial correlation problem. The granger causality test revealed that there exists a bidirectional relationship between natural gas and fiscal policy; oil revenue and a unidirectional causality between crude oil and fiscal policy, notably, government total expenditure. The impulse response function and Forecast Error Variance 
Decomposition results show that oil shocks exert noticeable influence on Nigeria's fiscal policy through fiscal channel of government expenditures that are funded by oil revenues. Also, the impact of crude oil and natural gas on innovations in fiscal policy shock was positive from the first, second, third forecast periods and was steady throughout and did not die out in the long run.

Okwara and Amori (2017) [20] addressed the influence of tax revenue on the economic growth in Nigeria for the period of 1994-2015. Secondary data were used and sourced from Central Bank of Nigeria's (CBN) statistical bulletin. The variables considered are: Gross Domestic Product (GDP) as a proxy for economic growth, Value Added Tax (VAT), and non-oil income (tax). To avoid spurious results, Ordinary Least Square (OLS) with the aids of Statistical Package for Social Sciences (SPSS) was used to test the significant impact of value added tax and non-oil income on Gross Domestic Product (GDP). The results revealed that non-oil income has significant impact on gross domestic product while value added tax has negative relationship and statistically insignificant for the period under review. The study concluded that tax revenue has significant impact on Nigerian economy growth. The study therefore recommended that government should diversify the main revenue source from crude oil to other sectors of the economy such as agriculture and extractive industries in order to attract direct and indirect taxes.

Kawai (2017) [21] evaluated the impact of Nigeria's non-oil exports as to whether they have been effective in diversifying the productive base of the Nigerian Economy from Crude oil as the major source of foreign exchange. The study investigated the specific impact of the non-oil exports to the growth of Nigerian economy using annual data between 1980-to-2016. The study adopted the Phillip Perron (PP), the Engel-Granger Model (EGM) for co-integration in its analysis. Findings revealed a strong evidence of cointegration relationship of non-oil exports in influencing rate of change in the level of economic growth in Nigeria.

Kromtit, Kanadi, Ndangra and Lado (2017) [22] examined the contribution of non oil export to the growth of the Nigerian economy for the period 1985-2015. Augmented Dickey Fuller was used to test for unit root and to ascertain the stationarity of the variables. The result showed non oil exports to be stationary at level while economic growth proxied by Gross Domestic Product (GDP) and exchange rate were stationary at first difference. Auto-regressive distributed lag (ARDL) model was then employed to ascertain the relationship between non oil exports and GDP. The Bound test conducted showed the presence of cointegration which means a long run relationship among the variables existed. The ARDL regression result indicated a positive and significant relationship between non oil exports and GDP. This means non oil exports contributed significantly to economic growth in Nigeria. The result also revealed that exchange rate had a negative though not significant relationship with GDP which is in line with economic theory. The study concluded a positive and significant relationship 
between the non-oil exports and Nigeria's economic growth proxied by GDP. That is, non-oil exports contributed significantly to the growth of Nigeria's GDP. The data collection for the study stopped at 2015. This study proceeds further to gather data to 2018 to make a difference in the literature and also to examine whether the non-oil trend will remain positive or not.

Aljebrin (2017) [23] empirically estimated the critical parameters of non-oil export impact on non-oil economic growth in Saudi Arabia for the period 1988-2014 by using ordinary least squares and error correction model approach. The empirical results obtained show that, in both short run and long run, there are positive and significant relationship between the non-oil economic growth and non-oil exports. There is also positive and significant relationship between non-oil economic growth and capital in both long run and short run. On the other hand, there is a positive and significant relationship between non-oil economic growth and labour in the long run but positive and insignificant in the short run. The error correction is correctly negatively signed and highly significant and has a large magnitude (-0.537) suggesting a rapid adjustment process, which means that, if non-oil gross domestic product is $1 \%$ out of equilibrium, a $53.7 \%$ adjustment towards equilibrium will take place within the first year.

Olayungbo and Olayemi (2018) [24] investigated the dynamic relationships among non-oil revenue, government spending and economic growth in Nigeria for the period of 1981 to 2015. After establishing a long run relationship among the variables, the error correction model and impulse responses were estimated as well as the granger causality test among the variables. The results of the short run and long run showed negative effects of government's spending on economic growth while non-oil revenue showed positive effect on economic growth. The study also found that non-oil revenue has negative shocks on economic growth while the government spending shock was positive. The Granger causality revealed that government spending granger caused both non-oil revenue and economic growth supporting the Keynesian and spend-tax hypothesis in Nigeria over the period of the study. The study does not only fail to use recent data but also did not reveal the type of non-oil sector revenue that was used. In the context of the present study, non-oil sector will be objectively classified.

Ogba, Park and Nakah (2018) [12] examined the impact of non-oil revenue on economic growth in Nigeria for the period of 1981-2016. Variables of Agricultural revenue contribution (ARC), Manufacturing Revenue Contribution (MRC), Solid mineral revenue contribution (SMRC), Services revenue contribution (SRC), company income tax (CIT) and custom and excise duties Tax (CED) representing the explanatory variables were regressed on the dependent variable of economic growth proxied by gross domestic product (GDP). Regression model was used to determine the relationship between economic growth and the non-oil revenue. The findings revealed that a long run relationship exists between the variables (ARC, MRC, SMRC, SRC, CIT, CED) and economic growth in Nigeria. Among the variables, ARC, MRC, SRC and CIT were found to have 
contributed substantially to the growth of Nigerian economy within the period under study. On the other hand, SMRC and CIT where found to have negative relationship with GDP. Again, SMRC and CED were statistically insignificant. The result of the error correction model was correctly signed showing that the system returns to equilibrium at the speed of about $80 \%$ if the system is exposed to external shock in the longrun.

Simionescu, Bilan, Krajňáková, Streimikiene and Gedek (2019) [25] assessed the importance of GDP per capita in realising the effects of the renewable energy sources (RES) share in electricity between 2007 and 2017. Contrary to previous research, the study does not consider the connection between economic growth and RES, but rather the potential connection between the share of RES in electricity and the real GDP per capita. The panel data models was employed and indicated to be positive, but very low impact of GDP per capita on the share of RES in electricity in the period of 2007-2017 in the case of the EU countries, except Luxembourg that has outlier values of GDP per capita. However, causality between the two variables was not identified.

Based on the contributions of scholars on oil and non-oil effects on economic growth in literature, it can be established that while Okezie and Azubike (2016) [1], Idris and Ahmad (2017) [17], Nwafor (2017) [18], Okwara and Amori (2017) [20] found positive effects others like Tabari and Nasrollahi (2010), Idowu (2016) [15], Ogba, Park and Nakah (2018) [12] found negative effects. Thus, without missing words, there is conflicting result in the study which could be attributed to scope, variables, data collection and methods. More importantly, none of the study has been able verify the significant of environmental, ICT, and financial sub-sector of non-oil sector on economic growth in literature. The study bridges this gap in literature by studying the importance of these non-oil sub-sectors on economic growth in Nigeria context and also to pave way for government's challenges.

\section{Methodology}

\subsection{Research Design}

This study adopted ex-post-factor research design in which investigation starts after the fact has occurred without interference from researcher. Therefore, historical facts about non-oil sector revenue and economic growth were obtained through the use of secondary data.

\subsection{Model Specification}

The empirical model of this study is based on the conclusion of the theoretical framework, in an effort to establish a relationship between sectorial contributions of non-oil revenue and economic growth. The study adapts the work done by Okezie and Azubike (2016) [1] on contributions of non-oil revenue to government revenue and economic growth in Nigeria. Their model is specified as:

$$
\mathrm{GDP}=f(\mathrm{TOREV})
$$


where:

GDP $=$ Gross domestic product

TOREV $=$ Total Government Revenue

$f=$ Functional notations

The present study modified the model proposed by Okezie and Azubike (2016) [1] by replacing the explanatory variables of oil total revenue and non oil total revenue with environmental sector revenue, ICT sector revenue and financial sector revenue respectively. The justification for these changes is to specifically investigate the extent to which government has been enjoying revenue base from environmental sector revenue, ICT sector revenue and financial sector against the common agricultural and manufacturing sectors. Based on this, the model for the study is, therefore, stated as:

$$
\mathrm{RGDP}=f(\mathrm{ESR}, \mathrm{ICTSR}, \mathrm{FSR})
$$

where:

RGDP $=$ Index of Gross Domestic Product (Real GDP) expressed in constant term.

$\mathrm{ESR}=$ Environmental sector revenue.

ICTSR $=$ ICT sector revenue.

FSR $=$ Financial sector revenue.

$f=$ Functional notation.

\subsection{Estimation Techniques}

The estimation techniques employed in this study is inferential statistics. The regression estimation technique of Autoregressive Distributed Lag Model (ARDL) is the main technique, however, prior to the ARDL regression test, other tests such as Augmented Dickey Fuller test for stationarity of the data are examined to know the level of stationarity among the variables before the main test which is ARDL to test the short and long run effects of non-oil revenue sector on economic growth in Nigeria. The regression test is stated as:

$$
\mathrm{RGDP}=\alpha_{0}+\alpha_{1} \mathrm{ESR}_{t}+\alpha_{2} \mathrm{ICTSR}_{t}+\alpha_{3} \mathrm{FSR}_{t}+\mu_{t}
$$

where:

$$
\begin{aligned}
& \alpha_{0}=\text { constant term. } \\
& \alpha_{1}-\alpha_{6}=\text { Coefficient of the parameters. } \\
& \mu_{\mathrm{t}}=\text { error term. } \\
& t=\text { time series. }
\end{aligned}
$$

Other variables remained as earlier defined.

\section{ARDL Approach to Co-Integration}

To examine the long run relationships between non-oil sector revenue and economic growth in Nigeria, this study uses recent co-integration analysis approach, known as autoregressive-distributed lag (ARDL) model (Pesaran, Smith \& Shin, 2001) To begin with, the study tests for the null hypothesis of no co-integration against the existence of a long run relationship. All other tech- 
niques require the same level of stationarity of variables for further process. But the ARDL model provides a substitute test for examining a long run relationship regardless of whether the underlying variables are $I(0), I(1)$, or fractionally integrated. This approach has the following econometric advantages in comparison to other Co-integration procedures.

1) The long and short-run parameters of the model in question are estimated simultaneously;

2) The ARDL approach for testing the existence of long-run relationship between the variables in levels is applicable irrespective of whether the underlying regressors are purely $I(0)$, purely $I(1)$, or fractionally integrated;

3) The small sample properties of the bounds testing approach are far superior to that of multivariate co-integration. The bounds testing approach of Pesaran et al. (2001) is employed to test the existence of a co-integration relationship among the variables.

4) The Pesaran et al. procedure involves investigating the existence of a long-run relationship in the form of the unrestricted error correction model for each variable. According to ARDL procedure, the unrestricted model of our concerned function is depicted as follow:

$$
\begin{aligned}
\ln (\mathrm{RGDP})_{t}= & \lambda_{0}+\sum_{i-1}^{n} \lambda_{1}+\Delta \ln (\mathrm{RGDP})_{t-1}+\sum_{i-1}^{n} \lambda_{2}+\Delta \ln (\mathrm{ESR})_{t-1} \\
& +\sum_{i-1}^{n} \lambda_{3}+\Delta \ln (\mathrm{ICTSR})_{t-1}+\sum_{i-1}^{n} \lambda_{4}+\Delta \ln (\mathrm{FSR})_{t-1} \\
& +\beta_{0} \ln (\mathrm{RGDP})_{t-1}+\beta_{1} \ln (\mathrm{ESR})_{t-1} \\
& +\beta_{2} \ln (\mathrm{ICTSR})_{t-1}+\beta_{3} \ln (\mathrm{FSR})_{t-1}+\mu_{i t}
\end{aligned}
$$

where $\operatorname{Ln}(\mathrm{RGDP})$ the natural logarithm of Real gross domestic product deflator is, $\operatorname{Ln}(\mathrm{ESR}), \operatorname{Ln}(\mathrm{ICTSR}), \operatorname{Ln}(\mathrm{FSR})$, are the natural logarithm of environmental sector revenue, ICT sector revenue and financial sector revenue, $\Delta$ is the difference operator and it $\mathrm{n}$ is the i.i.d stochastic error term. In order to investigate the long run relationship with restriction of coefficients $\alpha_{1}, \alpha_{2}, \alpha_{3}$, the null hypothesis in long run is written as follow:

$$
H_{0}=\alpha_{1}=\alpha_{2}=\alpha_{3}=0
$$

The F-test is used to test the existence of long-run relationships. Thus, the Pesaran et al. (2001) approach computes two sets of critical values for a given significance level. One set assumes that all variables are $I(0)$ and the other set assumes they are all $I(1)$. If the computed F-statistics exceeds the upper critical bounds value, then the $H_{0}$ (null hypothesis) is rejected. If the F-statistics falls into the bounds, then the test becomes inconclusive. Lastly, if the F-statistics is below the lower critical bounds value, it implies no co-integration. When long-run relationship exists, the F-test indicates which variable should be normalised. Moreover, when the order of integration of the variables is known and if all the variables are $I(1)$, then the decision is based on the upper bound value. Similarly, if all the variables are $I(0)$, then the decision is based on the lower bound. 
However, for policy reasons, the short-run adjustment of environmental sector revenue, ICT sector revenue, financial sector revenue, power sector revenue, wholesale and retail sector revenue and health sector revenue to changes in its determinants is necessary. To capture the speed of adjustment, we estimate the following dynamic error correction model depicted by the equation below:

$$
\begin{aligned}
\ln (\mathrm{RGDP})_{t}= & \lambda_{0}+\sum_{i=1}^{n} \lambda_{1}+\Delta \ln (\mathrm{RGDP})_{t-1}+\sum_{i=1}^{n} \lambda_{2}+\Delta \ln (\mathrm{ESR})_{t-1} \\
& +\sum_{i=1}^{n} \lambda_{3}+\Delta \ln (\mathrm{ICTSR})_{t-1}+\sum_{i=1}^{n} \lambda_{4}+\Delta \ln (\mathrm{FSR})_{t-1}+(\mathrm{ECM})_{t-1}
\end{aligned}
$$

where $\Delta$ represents first difference operator and $\mathrm{ECM}_{t-1}$ is the one period lag error correction term estimated from Equation (5). The error correction term coefficient got after estimation measures the speeds of adjustment to obtain equilibrium in the event of shocks to the system. After estimation of long run relationship by employing the selected ARDL model, there are varieties of diagnostic and stability tests to verify the goodness of the fit of the model. These diagnostic tests refer to the serial correlation, functional form, normality and heteroscedasticity associated with the model.

\subsection{Apriori Expectation}

Theoretically, all the explanatory variables of environmental sector revenue, ICT sector revenue and financial sector revenue are expected to have positive effects on economic growth in Nigeria. This is on the basis that efforts of the government to invest and support the activities of these sectors will tremendously impact economic growth in return by creating jobs and reducing level of poverty in the country. In the light of these, environmental sector revenue, ICT sector revenue and financial sector revenue are expected to increase economic growth in Nigeria.

Summarily,

$$
\begin{gathered}
\beta_{1}-\beta_{3}>0 \text { i.e. } \\
\beta_{1}>0 ; \quad \beta_{2}>0 ; \quad \beta_{3}>0
\end{gathered}
$$

\subsection{Measurement of Variables and Source of Data}

Real Gross domestic product Per Capita Growth (RGDP): This is the annual percentage of growth rate, GDP per capita is based on constant local currency. It measures economic performance. This is calculated as: Real GDP growth rate = (most recent year's real GDP, the last year's real GDP)/the previous year's real GDP. It is recorded in percentage

Environmental sector revenue: This is the annual revenue that is made from cleaning, waste collection and recycling.

ICT sector revenue: This refers to the aggregate income made from information, communication and technology sector over a period of a fiscal year.

Financial sector revenue: This is the annual revenue got from banking and insurance services in the country. 
The data that this study proposed to employ are chiefly based on secondary data. The variables are Real GDP and environmental sector revenue, ICT sector revenue, financial sector revenue, and were sourced and obtained from the annual publication of Central Bank of Nigeria Statistical Bulletin.

\section{Result and Discussion}

Before applying the unit root test, it is needful to present graphical figures of the variables in order to observe their movements, patterns and behaviours for outliers, aberrant observations and structural breaks (Perron, 1998) [26].

\subsection{Trend Analysis}

Figure 1 to Figure 4 presented above illustrate the trend of the series in the model under discussion. Figure 1 showed an upward trend from 1981 to 2018, this implies that real gross domestic has been on the increase from 1981 to 2018 as a result of different structural reforms and programme. Figure 2 indicated the trend of environmental sector revenue which posed no true trend from 1981 to 1994, however from 1995 to 2018, the variable received a sporadic and sharp upward trend which can be attributed to government intervention, that is, allocating of financial resources into the sector. Figure 3 represents the trend of information and communication technology sector revenue which became slightly noticed in 1986 to 1987 period as a result of structural adjustment programme, however, between 1987 and 1999 the trend was horizontal until 2000 when the trend arose throughout the period. Figure 4 represents financial sector revenue which was fixed from 1986 to 1989 but became trendy on a slow pace between 1990 and 1994 and by 1995, the trend became pronounced significantly as a result of increase in revenue base of financial sector to the economic, this increase is attributed to the efforts of monetary authorities at periodic intervals thereby enhancing that financial sector revenue promote economic stability of the country. Nonetheless, there is a significant decline from 2010 to 2011 which can be attributed to aftermath of global financial crisis between 2007 and 2008.

\subsection{Correlation Analysis}

Table 1 showed that there is a positive relationship between real gross domestic product and environmental sector revenue to the tune of 0.877735 , reflecting that both variables, real gross domestic product and environmental sector revenue move towards the same directions. The same explanation holds for the relationship between real gross domestic product and information and communication technology sector revenue with a correlation coefficient of 0.947812 . The result equally showed that real gross domestic product maintained a positive relationship with financial sector revenue with the correlation coefficient of 0.956103. The relationship between all the predictor variables is positive all through, reflecting that they all maintained a positive relationship with real gross domestic product. 


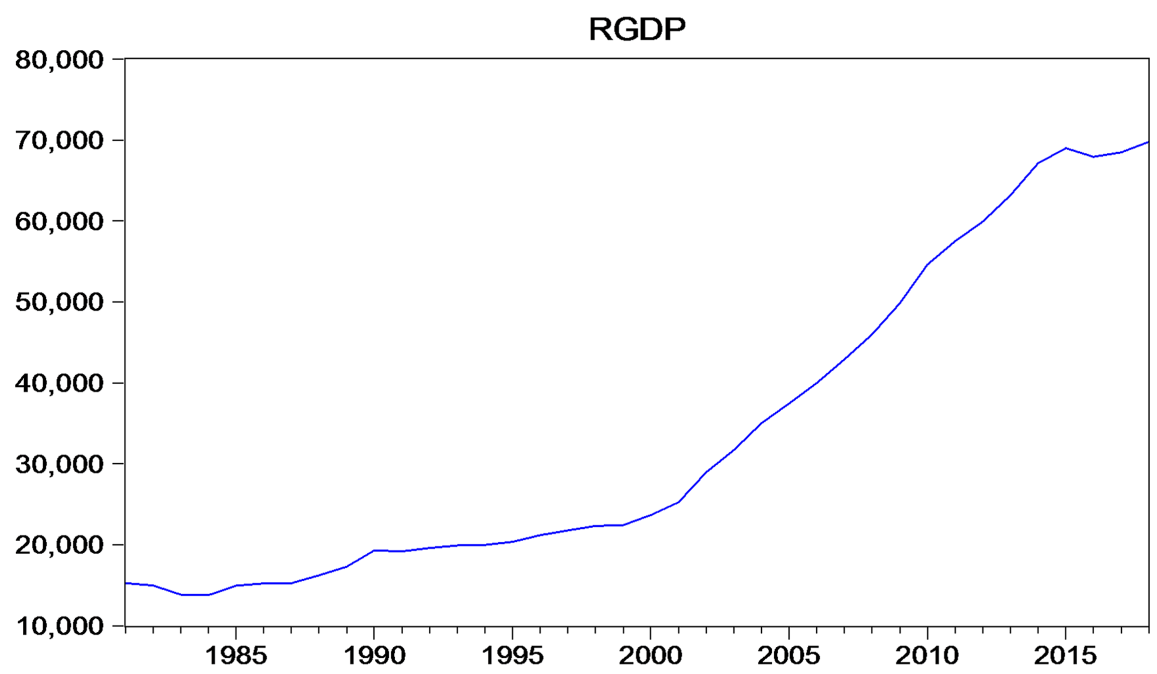

Figure 1. Real gross domestic product.

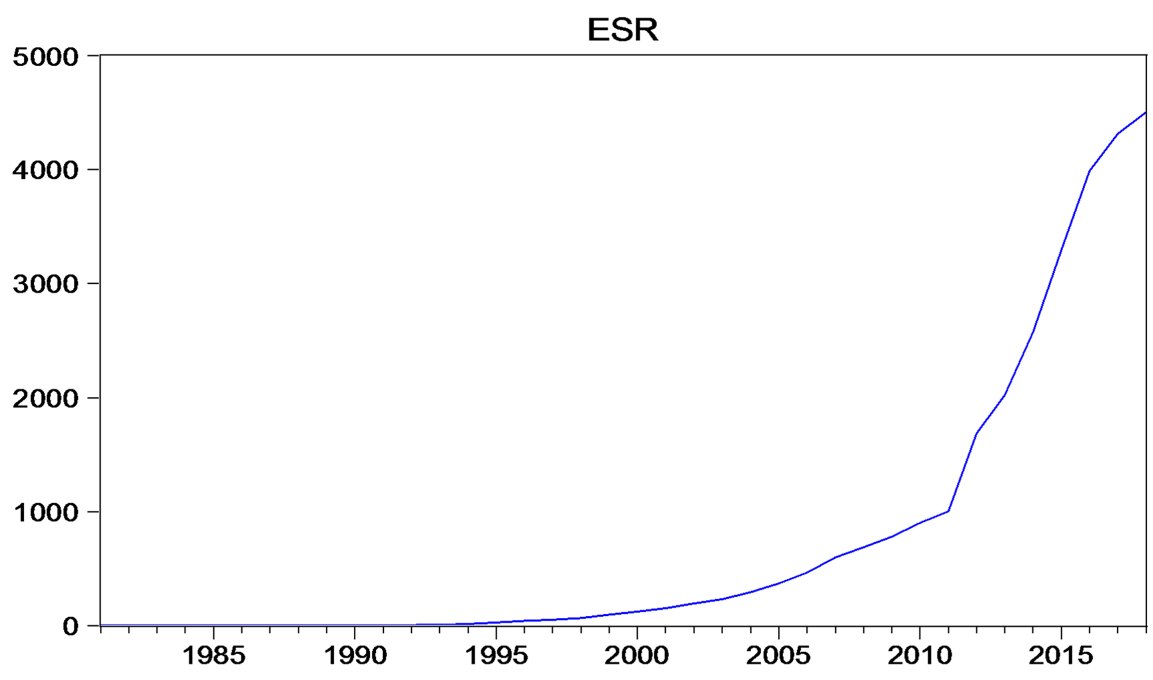

Figure 2. Environmental sector revenue.

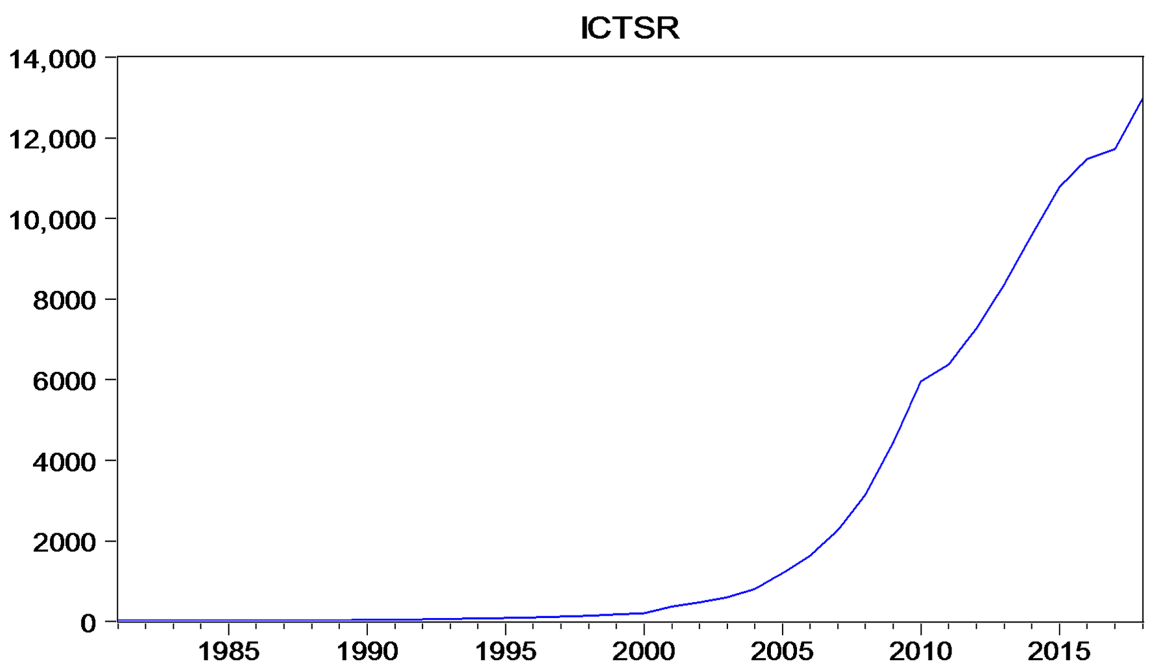

Figure 3. ICT sector revenue. 


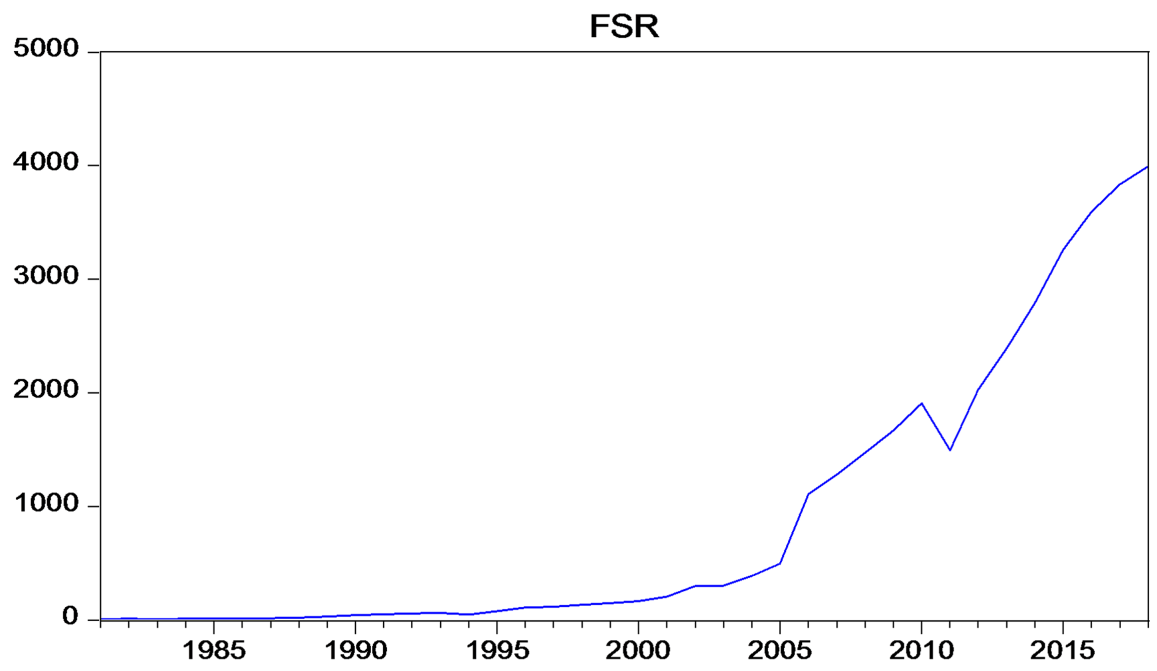

Figure 4. Financial sector revenue.

Table 1. Correlation statistics.

\begin{tabular}{ccccc}
\hline & RGDP & ESR & ICTSR & FSR \\
\hline RGDP & 1 & & & \\
ESR & 0.877735 & 1 & & \\
ICTSR & 0.947812 & 0.968709 & 1 & 1 \\
FSR & 0.956103 & 0.968200 & 0.988137 & \\
\hline
\end{tabular}

Source: E-view 9, Statistical Package.

\subsection{Unit Root Test}

The unit root test is conducted to determine whether the variables are stationary and to determine the order of integration of the variables using the Augmented Dickey-Fuller (ADF) test.

Table 2 showed the result of the Augmented Dickey-Fuller unit root test. Discovery from the result explicitly showed that ICTSR was stationary at level while other variables of RDGP, ESR, FSR attained stationarity after differencing, i.e. at first difference and at $5 \%$ and $1 \%$ level of significance respectively. The economic implication of this is that any shock or disturbance (e.g. government policy) to the variables will not be sustained for a long period of time meaning such shock will die off in a short while. Hence, since there is evidence of $I(0)$ and $I(1)$ level of integration which justify the usage of Autoregressive Distributed Lag model (ADRL).

\subsection{ARDL Bound Cointegration}

Table 3 revealed that the computed F-stat of 6.254343 is greater than the Upper Bound table value at any \% level of significance. The study rejects the null hypothesis which confirmed the presence of long-run relationship among the variables, that is, the variables co-move on the long run. 
Table 2. Unit root test.

\begin{tabular}{cccccc}
\hline \multirow{2}{*}{ Variables } & Test statistics & \multicolumn{3}{c}{ Critical value } & Order of \\
\cline { 3 - 5 } & & $1 \%$ & $5 \%$ & $10 \%$ & Integration \\
\hline RGDP & -6.493484 & -3.632900 & -2.948404 & -2.612874 & $\mathrm{I}(1)^{* * *}$ \\
ESR & -5.943360 & -3.632900 & -2.948404 & -2.612874 & $\mathrm{I}(1)^{* * *}$ \\
FSR & -4.396111 & -3.632900 & -2.948404 & -2.612874 & $\mathrm{I}(1)^{* *}$ \\
ICTSR & -4.093285 & -3.626784 & -2.945842 & -2.611531 & $\mathrm{I}(0)^{* *}$ \\
\hline
\end{tabular}

Note: ${ }^{*}\left(^{* *}\right)\left({ }^{* *}\right)$ denotes null hypothesis at $10 \%, 5 \%$ and $1 \%$ level of significant respectively. Source: E-view 9, Statistical Package.

Table 3. ARDL bound test.

\begin{tabular}{ccccc}
\hline & & \multicolumn{3}{c}{ Critical Values Bounds } \\
\cline { 3 - 5 } Null Hypothesis & F-Statistic & Significance & Lower Bound & Upper Bound \\
\hline & & $10 \%$ & 2.12 & 3.23 \\
$\begin{array}{c}\text { No long-run } \\
\text { relationships } \\
\text { exist }\end{array}$ & 6.254343 & $5 \%$ & 2.45 & 3.61 \\
& $2.5 \%$ & 2.75 & 3.99 \\
\hline
\end{tabular}

Source: E-view 9, Statistical Package.

\subsection{Long and Short Run Estimation Coefficients}

Having confirmed the existence of long-run relationship among the variables, the study will estimate long run and short run parameters by general to specific procedure ARDL model.

The result presented in Table 4 disclosed ceterisparibus, when all the explanatory variables were held constant, the economic growth proxied by real gross domestic product of Nigeria will significantly increase by $11.99 \%$ in the long run. More so, the coefficient of environmental sector revenue implies a positive with an insignificant effect on economic growth. Thus, revenue from environmental sector will insignificantly spur the activities of economic growth by $6.62 \%$. The coefficient of information and communication technology sector has a positive with a significant effect on economic growth. By implication, any percent change in the activity of information and communication technology sector will positively and significantly increase the revenue base of ICT sector to economic growth by $5.94 \%$. Furthermore, the coefficient of financial sector revenue stands at 18.3514 which is positive and statistically significant at $5 \%$ level of significance. The result connotes that a percent change in financial sector will positively and significantly affect the revenue from this sector channeled to economic growth by $18.25 \%$.

Theoretically, all these result are expected and conformed to the positive re- 
sult of the earlier apriori expectation. The result connotes that in the long run, sectorial contributions of non-oil sector have positive effects with a significant contributions to economic growth in Nigeria. This result is connected with the existing empirical study of Ogba, Park and Nakah (2018) [12] that non-oil sector contributed positively and significantly to economic growth in Nigeria in the long run.

\subsection{The Short-Run Dynamic and the Error Correction Model}

The result in Table 5 indicated that the coefficient of the error correction term ECM $(-1)$ has the correct sign and significant at $5 \%$ level. The value of the coefficient is -0.603477 . The result showed that about $60.35 \%$ of the short-run inconsistencies are being corrected and incorporated into the long-run equilibrium relationship in each period. In other word, it can be said that the level at which non-oil sector adjust to equilibrium was about $60.35 \%$. This, therefore, implied that $60.35 \%$ of the discrepancy between long and short run level of non-oil sector revenue in Nigeria was corrected and incorporated annually.

The short run result revealed that environmental sector revenue has positive with an insignificant effect on economic growth. Thus, in the short run, environmental sector contributed about $2.69 \%$ revenue to economic growth in Nigeria. This result is in alignment with the long run result. Simultaneously, both in

Table 4. Long run co-integrating coefficients.

\begin{tabular}{|c|c|c|c|c|}
\hline \multicolumn{5}{|c|}{ Long Run Coefficients } \\
\hline Variable & Coefficient & Std. Error & t-Statistic & Prob. \\
\hline $\mathrm{C}$ & $11,992.6627$ & 772.44999 & 15.525488 & 0.0000 \\
\hline ESR & 6.623073 & 6.432604 & 1.029610 & 0.3176 \\
\hline ICTSR & 5.944861 & 1.689936 & 3.517803 & 0.0026 \\
\hline FSR & 18.351434 & 7.338067 & 2.500854 & 0.0229 \\
\hline
\end{tabular}

Source: E-view 9, Statistical Package.

Table 5. The short-run cointegrtaion.

\begin{tabular}{ccccc}
\hline Variable & Coefficient & Std. Error & t-Statistic & Prob. \\
\hline $\mathrm{D}(\mathrm{RGDP}(-1))$ & 0.232626 & 0.212001 & 1.097286 & 0.2878 \\
$\mathrm{D}(\mathrm{ESR})$ & 2.695084 & 2.781077 & 0.969079 & 0.3461 \\
$\mathrm{D}(\mathrm{ICTSR})$ & 2.264555 & 1.023284 & 2.213027 & 0.0409 \\
$\mathrm{D}(\mathrm{FSR})$ & -2.943705 & 1.894437 & -1.553868 & 0.1386 \\
$\mathrm{D}(\mathrm{FSR}(-1))$ & 6.453363 & 2.236236 & 2.885815 & 0.0103 \\
$(\mathrm{ECM}-1)$ & -0.603477 & 0.198556 & -3.039320 & 0.0074 \\
\hline
\end{tabular}

Source: E-view 9, Statistical Package. 
the short and long run, revenue from environmental sector will insignificantly and positively contributed to economic growth in Nigeria. The result also showed that revenue from information and communication technology sector contributed positively and significantly to economic growth in Nigeria by $2.26 \%$. Thus, when attention and dedication is given to information and communication technology sector, the returns from the sector will significantly improve the value of economic growth by $2.26 \%$. The significant contributions is not different from what was recorded in the long run, thus both in the short and long run, revenue from ICT sector will significantly increase economic growth in Nigeria. The financial sector however has a negative and insignificant contribution to economic growth in the short run. This shows that, revenue from financial sector contributed negatively to the growth of Nigerian economy. Nonetheless, when the variable is lagged it became positive and significant, implying that revenue from financial sector contributed positively and significantly to economic growth in Nigeria.

\subsection{Test and Validation of Hypotheses}

This section presents a summary of the hypotheses tested in the study. Hypotheses are tested based on the significance of the reported coefficient estimate corresponding to variables of interest in this study. Notably, all the hypotheses of this study were tested using the probability values reported for the parsimonious ECM result.

Hypothesis: Environmental, ICT and financial sectors revenue have no significant contributions to economic growth in Nigeria

Table 6 revealed that there is enough evidence to accept the null hypothesis that Environmental sector revenue has no significant contributions to economic growth in Nigeria. Thus, the study rejects the alternate hypothesis and accepts the null hypothesis to conclude that environmental sector revenue exerts a positive with an insignificant contribution to economic growth in Nigeria. The table further revealed that there is enough evidence to reject the null hypothesis that ICT sector revenue has no significant contributions to economic growth in $\mathrm{Ni}$ geria. Thus, the study rejects the null hypothesis and concluded that ICT sector revenue has a positive with significant contributions to economic growth in $\mathrm{Ni}$ geria. Lastly, the table revealed that there is enough evidence to reject the null

Table 6. Environmental, ICT and financial sectors revenue and economic growth in Nigeria.

\begin{tabular}{lcccc}
\hline Null hypothesis & Variables & Coefficient estimate & Probability & Remark \\
\hline $\begin{array}{c}\text { Coefficient is not } \\
\text { statistically } \\
\text { significant }\end{array}$ & Environmental & 2.695084 & $0.346>0.05$ & Accept $\mathrm{H}_{0}$ \\
& ICT & 2.264555 & $0.040<0.05$ & Reject $\mathrm{H}_{0}$ \\
& Financial & 6.453363 & $0.010<0.05$ & Reject $\mathrm{H}_{0}$ \\
\hline
\end{tabular}

Source: Data analysis (2020). 
hypothesis that financial sector revenue has no significant contributions to economic growth in Nigeria. Thus, the study rejects the null hypothesis and concluded that financial sector revenue has positive with a significant contributions to economic growth in Nigeria. Hence, it can be concluded that ICT and financial sectors have positive with a significant contributions to economic growth while environmental sector has positive with an insignificant effect on economic growth in Nigeria.

\section{Discussion and Recommendation}

The study empirically investigated the sectorial contributions of non-oil revenue to economic growth in Nigeria using a time series data spanning from 1981 through 2018. The study employed inferential statistics such as correlation analysis, unit root test, autoregressive distributed lag model and error correction mechanism to ascertain the short and long run relationships of environmental sector revenue, information and communication technology sector revenue and financial sector revenue to economic growth proxies as real gross domestic product.

Result of the correlation analysis discovered that there is a direct relationship between all the predictor variables all through, reflecting that they all maintained a positive relationship with real gross domestic product. The Augmented Dickey-Fuller unit root test disclosed that ICTSR attained stationary at level and at $5 \%$ level of significance while other variables of RDGP, ESR and FSR attained stationarity after differencing, i.e. at first difference and at 5\% and $1 \%$ level of significance respectively. Furthermore, result from ARDL showed that the computed F-stat is greater than any of the upper and lower bound table value which thus indicated that there is a long-run relationship among the variables, that is, the variables co-move in the long run. This result validated the empirical finding of Aladejare and Saidi (2014) [27] that there is a long-run relationship between non-oil contributions and economic growth in Nigeria.

The significance of these sectors may be attributed to the attention that governments have given to these sectors over time, which in turn yields positive effect by increasing the revenue base of the government in Nigeria. The result is expected and consistent with the empirical finding of Salami, Amusa and Ojoye (2018) [28] that non-oil sector positively and significantly contributed to economic growth in Nigeria. More surprising, the result emanating from short run analysis is in tandem with the long run result. This therefore implies that in the short run and long run respectively, non-oil sectorial contributions positively and significantly contributed to economic growth in Nigeria. The study agreed with the empirical finding of Kromtit, Kanadi, Ndangra and Lado (2017) [22] that non-oil sector contributed positively and significantly to economic growth.

Thus, private sector owners and managers that capitalized on oil businesses can increase their net worth by shifting into non-oil sectorial businesses like health, finance, trade, power, ICT unlike Agriculture and manufacturing which 
many people are frequently diverting into. Diversification of the economy into non-oil sector is quintessentially important at a time like this by not wholly depending on oil sector as the sole and main contributor to the government's revenue and RGDP. Thus, environmental, ICT, financial among others non-oil sectors should receive the same magnitude of fund as in the case of oil sector, i.e., the sector should be more funded and well equipped to ensure good outputs and contributions; Government should review environmental factors and policy that may spur the economy significantly.

In order to better enhance literature on this topic, future researchers are implore to get up to-date secondary data across other sectors not applicable in this study, this will aid comparison among the sub-sector of non-oil sector in the country.

\section{Conflicts of Interest}

The authors declare no conflicts of interest regarding the publication of this paper.

\section{References}

[1] Okezie, S.O. and Azubike, J.U. (2016) Evaluation of the Contribution of Non Oil Revenue to Government Revenue and Economic Growth: Evidence from Nigeria. Journal of Accounting and Financial Management, 2, 41-51.

[2] Sanusi, J.O. (2003) Developing the Non-Oil Sector in Nigeria. The 8th Monetary Policy Forum, Abuja.

[3] Ude, D.K. and Agodi, J.E. (2014) Investigation of the Impact of Non-Oil Revenue on Economic Growth in Nigeria. International Journal of Science and Research, 3, 2571-2577.

[4] Adulagba, D. (2011) Executive Director/CEO, NEPC in Onuba, I., 2012, Non-Oil Export Trade, Punch, April 16, 2012.

[5] Onwualu, A.P. (2012) Growth and Development of the Nigerian Non-Oil Sector: Key to Successful Economic Diversification. The 51 AGM Conference of NACCIMA, Sagamu.

[6] Dauda, T.O., Asiribo, O.E., Akinbode, S.O., Saka, J.O. and Salihu, B.F. (2009) An Assessment of the Roles of Irrigation Farming in the Millennium Goals.

[7] Ayuba, A.J. (2014) Impact of Non-Oil Tax Revenue on Economic Growth: The Nigerian Perspective. International Journal of Finance and Accounting, 3, 303-309.

[8] Garba, S.L. (2014) Tax Revenue and Economic Growth. PhD Thesis, Postgraduate Studies, Ahmadu Bello University, Zaria.

[9] National Bureau of Statistics (2014) Revised and Final GDP Rebased Result by Output Approach. National Bureau of Statistics, Abuja.

[10] Izuchukwu, O. (2011) Analysis of the Contribution of Agriculture Sector on the Nigerian Economy Development. World Review of Business Research, 1, 191-200.

[11] Ihendinihu, J.U., Ebieri, J. and Amaps, I.E. (2014) Assessment of the Longrun Equilibrium Relationship between Tax Revenue and Economic Growth in Nigeria: 1986 to 2012. The SIJ Transaction on Industrial, Financial \& Business Management, 2, 1-15. https://doi.org/10.9756/SIJASREE/V2I5/0202120102 
[12] Ogba, L.J., Park, I. and Nakah, M.B. (2018) The Impact of Non-Oil Revenue on Economic Growth in Nigeria. International Journal of Advanced Research in Accounting, Economics and Business Perspectives, 2, 1-14.

[13] Ullah, F. and Rauf, A. (2013) Impacts of Macroeconomic Variables on Economic Growth: A Panel Data Analysis of Selected Asian Countries. GE International Journal of Engineering Research, 2, 163-179.

[14] Haller, A.P. (2012) Concepts of Economic Growth and Development. Challenges of Crisis and of Knowledge. Economy Transdisciplinarity Cognition, 15, 66-71.

[15] Idowu, R. (2016) Analysis of the Effects of Oil and Non-Oil Export on Economic Growth in Nigeria.

[16] Nweze, P.N. and Edame, G.E. (2016) An Empirical Investigation of Oil Revenue and Economic Growth in Nigeria. European Scientific Journal, 12, 271-294. https://doi.org/10.19044/esj.2016.v12n25p271

[17] Idris, M. and Ahmad, T.S.T. (2017) Tax Revenue and Macroeconomic Growth in Nigeria: A Contextual Analysis. Asian Journal of Economics, Business and Accounting, 3, 1-12. https://doi.org/10.9734/AJEBA/2017/33362

[18] Nwafor, M.C. (2017) An Empirical Approach to the Effect of Non-Oil Export on Nigerian Economy. International Journal of Advance Research, 5, 1430-1438. https://doi.org/10.21474/IJAR01/4555

[19] Apere, T.O. (2017) Impact of Crude Oil on Nigeria's Fiscal Policy Formulation. European Journal of Research in Social Sciences, 5, 74-83.

[20] Okwara, C.C. and Amori, O.M. (2017) Impact of Tax Revenue on Economic Growth in Nigeria. International Journal of Scientific Research in Social Sciences \& Management Studies, 2, 90-102.

[21] Kawai, V. (2017) An Analysis of the Impact of Non-Oil Exports and Economic Growth in Nigeria from 1980-2016. International Journal of Innovative Research in Social Sciences \& Strategic Management Techniques, 4, 83-94.

[22] Kromtit, M.J., Kanadi, C., Ndangra, D.P. and Lado, S. (2017) Contribution of Non Oil Exports to Economic Growth in Nigeria (1985-2015). International Journal of Economics and Finance, 9, 253-261. https://doi.org/10.5539/ijef.v9n4p253

[23] Aljebrin, M.A. (2017) Impact of Non-Oil Export on Non-Oil Economic Growth in Saudi Arabia. International Journal of Economics and Financial Issues, 7, 389-397.

[24] Olayungbo, D.O. and Olayemi, O.F. (2018) Dynamic Relationships among Non-Oil Revenue, Government Spending and Economic Growth in an Oil Producing Country: Evidence from Nigeria. Future Business Journal, 4, 246-260. https://doi.org/10.1016/j.fbj.2018.07.002

[25] Simionescu, M., Bilan, Y., Krajnáková, E., Streimikiene, D. and Gedek, S. (2019) Renewable Energy in the Electricity Sector and GDP per Capita in the European Union. Energies, 12, 2520. https://doi.org/10.3390/en12132520

[26] Perron, P. (1989) The Great Crash, Oil Price Shock and the Unit Root Hypothesis. Econometrica, 57, 136-401. https://doi.org/10.2307/1913712

[27] Aladejare, S.A. and Saidi, A. (2014) Determinants of Non-Oil Export and Economic Growth in Nigeria: An Application of the Bound Test Approach. Journal for the Advancement of Developing Economies, 3, 69-83.

[28] Salami, G.O., Amusa, B.O. and Ojoye, O.F. (2018) Empirical Analysis of the Impact of Non-Oil Revenue on Economic Growth: Nigerian Experience. International Journal of Economics, Commerce and Management, 6, 263-276. 